\begin{tabular}{|c|c|}
\hline \multirow{3}{*}{ 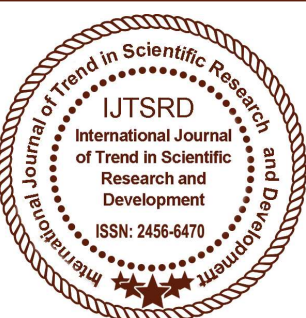 } & $\begin{array}{l}\text { International Journal of Trend in Scientific } \\
\text { Research and Development (IJTSRD) }\end{array}$ \\
\hline & International 0 \\
\hline & ISSN No: 2456 - 6470 | www.ijtsrd.com | Volume - 2 | Issue - 5 \\
\hline
\end{tabular}

\title{
India's Legal System has Failed to Learn From Institutional Memory
}

\author{
Saket Dev Pandey \\ B.B.A., L.L.B. ( Hons ) - IV ${ }^{\text {th }}$ Sem, Indore Institute of Law, \\ Indore, Madhya Pradesh, India
}

\section{The Judiciary}

Indian Judiciary is one of the most known and prominent one all over the world. Being the largest democracy Indian Judiciary is always in Light."The Constitution of India secures justice to all its citizens apart from securing liberty, equality, and promoting fraternity. Indian democracy the Supreme Court plays important role of safeguarding the fundamental rights of citizens which includes providing fair justice also. Justice which is the soul of a democratic society must be administered without fear or favor. Integrity, Impartiality and Intelligence are some of the important characteristics of the in dependent judiciary in a democratic setup."

The Supreme Court of India is the highest court of law, the entire judicial system of the country is controlled by it. Article 124 of the Constitution provides for the establishment and the composition of the Supreme Court. Article 131 to 140 deeds with the powers of the Supreme Court. The Supreme Court of India has three kinds of jurisdiction:

Original jurisdiction (ii) Appellate jurisdiction (jii) Advisory jurisdiction.

Under Article 131 of the Constitution, the Supreme Court has Original. jurisdiction in any dispute arising between Union and one or more States and between two or more states. Such a dispute should, however, involve some question of law or fact on which the existence or extent of legal rights depends. Under Article 133 and 134, an appeal may lie to the Supreme Court in any Civil or criminal proceeding of a High Court. The advisory function of the Supreme Court is also very important. If there arises any ambiguity regarding the interpretation of a clause of the constitution or certain constitutional problem arises, the President can refer the same to the Supreme Court for its expert opinion,

The Supreme Court of India is a court of record which means that the records of its decisions and proceedings are preserved and published. The decisions of the Supreme Court are binding on all the courts of India. The Supreme court also has powers to review its own judgment or order. The Supreme Court of India is the highest judiciary body, responsible to ensure justice to all. The Supreme Court under Article 142 of the Constitution has the constitutional mandate to pass such order as may be necessary for doing complete justice in any case before it. All authorities, civil or judicial are under obligation to follow such orders.

In Indian democracy, the Supreme Court plays important role of safeguarding the fundamental rights of citizens which includes providing fair justice also. Justice which is the soul of a democratic society, must be administered without fear or favor. Integrity, Impartiality and Intelligence are some of the important characteristic independent judiciary in a democratic setup.

It is a matter of academic discussion as to who really controls the process of Justice, whether the courts or the governments. So far the criminal cases are concerned; all the investigations are done by the police or other governmental agency which report to the government. Prosecutors are appointed by the government also. Courts are concerned with the trial. Thus two important aspects which constitutes justice Investigation and prosecution are totally in the hands of Government. 
The Government also provides funds for the smooth functioning of the courts. By regulating the flow of funds, the Government controls the capacities of courts directly. Better equipped courts with better and sufficient staff can deliver justice faster and more efficiently. Justice being a concurrent subject, both the Central and State governments are responsible for providing funds. The government indirectly controls even the process of trial through its control on funding.

The Central allocation of the tenth five year plan (2002-2007) for justice is merely Rs.700 Crore, comparing with the government's recent decision of spending Rs.727 crore on the purchase of five aircrafts for the use of VIPs, can well reveal the paradox. Setting up of fast track courts, family courts, consumer courts, special courts for ST/ST cases, has speeded up the procedure of justice. As such it has been decision of the government, which can speed up delivering justices.

No doubt the courts are duty bound to provide, fair and expeditious justice. The points of efficiency are many times in conflict. The increasing workload of the courts raises the matter of writing and publishing of judicial proceedings, decision and orders. The existing practice of writing and reporting judicial proceedings, decisions and orders needs to be reviewed carefully in order to enhance the efficiency of the courts. A very alarming situation the Indian judiciary faces today is the burgeoning arrear of pending cases, not only with the lower courts, but also with the Supreme Court. Delay in disposal of cases frustrates the very purpose of justice. Delayed justice is denied justice. Delay creates frustration and results in loss of confidence among the general mass. A sense of despair and frustration is inevitable in any individual, who unfortunately entangles in litigation. There is no certainty of provider of getting the final justice. In civil cases, the minimum time is supposed to be ten to fifteen years. What is the sense of having such a judicial system, which delivers justice after such a long period. In many cases, after the death of the original plaintiff. Even If a judgment is passed by a lower court, an appeal can be filed in high court as well as in Supreme Court. ${ }^{1}$

History of Supreme Court - Powers, Culture and Achievement

\footnotetext{
${ }^{1}$ ( http://www.preservearticles.com/201103034384/essay-onindian-judiciary-system.html )
}

\section{The Birth of Judiciary}

The concept of Dharma or law in ancient India was inspired by the Vedas which contained rules of conduct and rites and compiled in Dharma Sutras, were practiced in a number of branches of the Vedic schools. Their principal contents address the duties of people at various stages of life, the rights and duties of the kings and juridical matters. These were basis of Hindu Law.

The earliest document throwing light on the theory of jurisprudence, which forms part of practical governance, is the Artha Sastra of Kautilya dating back to circa 300 B.C. The third chapter deals with Vyavahara i.e. transactions between two or more parties or Vivada or disputation.

During the first seven centuries of Christian era, there evolved a number of Dharma sastras which dealt extensively with Manu, Yajnavalkya, Narda and Parashara smiritis etc. In medieval India, the religious leaders endeavoured to transform Islam into a religion of law, but as custodian of justice, the rulers made the Sharia, a court subservient to their sovereign power. Theoretically the rulers had to be obedient to the Sharia and history speaks about certain cases where sovereigns' unhesistengly submitted to the Qazi's decision. The rulers sat in a Court known as Mazalim (complaints). According to Ibn Battuta, Muhammad bin Tughalaq, ruler of Tughalaq dynasty, heard complaints each Monday and Thursday. From 13th century onwards, an officer known as Amir-i- dad presided over the secularCourt in sultan's absence. He was also responsible for implementing Qazis' decisions and for drawing their attention to the cases which constituted miscarriage of justice.

The Muftis were the expert on Sharia law and gave Fat was (formal legal rulings) on disputes referred to them by members of the public or qazis. The Chief Judge of the sultanate was known as the qazi -imamalik also known asthe qazi- ul- quzat.

During Mughals period the secular judge was known as Mir- adl. He acted as a judge on the Emperor's behalf. He was required to make impartial and personal inquiries. He was also responsible for implementing qazi's decisions. Emperor Akbar also appointed two officers, called tui-begis, to supervise the adherence to the law and fixed a nominal amount 
as their fee. The same system was followed till British took over the power of India.

\section{Birth of Supreme Court of India}

The promulgation of Regulating Act of 1773 by the King of England paved the way for establishment of the Supreme Court of Judicature at Calcutta. The Letters of Patent was issued on 26 March 1774 to establish the Supreme Court of Judicature at Calcutta, as a Court of Record, with full power \& authority to hear and determine all complaints for any crimes and also to entertain, hear and determine any suits or actions against any of His Majesty's subjects in Bengal, Bihar and Orissa. The Supreme Courts at Madras and Bombay was established by King George - III on 26 December 1800 and on 8 December 1823 respectively.

The India High Courts Act 1861 was enacted to create High Courts for various provinces and abolished Supreme Courts at Calcutta, Madras and Bombay and also the Sadar Adalats in Presidency towns. These High Courts had he distinction of being the highest Courts for all cases till the creation of Federal Court of India under the Government of India Act 1935. The Federal Court had jurisdiction to solve disputes between provinces and federal states and hear appeal against Judgements from High Courts. After India attained independence in 1947, the Constitution of India came into being on 26 January 1950. The Supreme Court of India also came into existence and its first sitting was held on 28 January 1950.

\section{Part 3: Appointment of the Judges}

Every Judge of the Supreme Court is appointed by the President after consultation with the Judges of the Supreme Court and High Courts in states, the president may deem necessary for the purpose. President if thinks necessary, can consult the Judges of the High Courts of States to appoint a supreme court Judge, as per article 124(2). However, in appointment of the other judges, president shall always seek consultation from the Chief Justice of India. Till 1993, the Judges of the Supreme Court were appointed by the President on recommendation of the CJI, but now a committee of 5 senior most judges recommends the names to the law ministry which after scrutinizing send the paper to the president. The president either approves the names or returns the names for reconsideration of the Supreme
Court. If still the Supreme Court sends the same names president appoints the persons recommended.

\section{Part 4: Qualifications of the Judges of the Supreme Court}

To be appointed a Judge of the Supreme Court, a person must be a citizen of India and must have been the judge of a high court for a period of 5 years or an advocate of the High Court for at least 10 years or in view of the President a distinct Jurist of the country. Thus, there is nothing which can prevent the direct appointment of the Judges of Supreme Court from the Bar, yet, so far the appointments have been made from the Judges of High Courts only.

\section{Part 5: Tenure of the Judges}

The CJI and other Judges of the Supreme Court of India hold the office until they attain the age of 65 years \{ Presently, Supreme Court judges retire at 65 and High Court judges at 62$\}$. A Judge can relinquish the office by addressing the resignation to President of India. A retired Judge of the Supreme Court is prohibited from practicing law before any court or authority within the territory of India; however, there is NO constitutional prohibition that a retired judge gets appointed for some specialized work of the Government.

\section{Part 6: Removal of Supreme Court Judges}

A Judge of the Supreme Court (and also High Court) can be removed from his position by President only on the ground of proved misbehaviour or incapacity. The power for investigation and proof of such misbehaviour or incapacity is vested in the parliament. Each house, in order to remove the judge, will have to pass a resolution which is supported by $2 / 3$ rd of members present and voting and majority of the total membership of the house \{absolute + special majority\}

\section{Part 7: Salary of the Supreme Court Judges}

The Constitution of India gives the power of deciding remuneration to the Parliament of India. Accordingly, such provisions have been laid down in The Supreme Court Judges (Salaries and Conditions of Service) Act, 1958. This remuneration was revised in 20062008, after the sixth central pay commission's recommendation

The salary and pension of Supreme Court Judges is a Non votable expenditure charged from the Consolidated Fund of India. The Salary of the High 
Court Judges is charged from the Consolidated Fund of States while the pension of the High Court Judges is charged from the consolidated fund India.

\section{Part 8: When CJI is absent}

Any other Judge of the Supreme Court is appointed by the President as Acting Chief justice as per provisions of Article 126.

So these were some information related to History, power and provisions of Indian Judiciary and Supreme Court ${ }^{2}$.

\section{Current Scenario of Legal System -}

Indian Judicial system, just like our country has come a long way from a system that had many flaws set up during the British rule, to the modern day watchdog of both the 'legislature' as well as the 'executive' of India; a country which is predicted by many to become a economical powerhouse by 2030. In fact the "Wealth Report" published by Knight Frank \& City Private Bank predicts that India will overtake China by 2050. Any country to have a booming market should have certain basic features. A legislature which can induce the faith of the investors through its policies, an executive in which the plague of corruption is contained to the maximum extent possible and a judiciary system to ensure both the legislature and the executive are doing what they are supposed to do.

Now here is the first question that pops up into the mind of a person who likes logic and reasoning behind a proposition, "Will this prediction become a reality considering the present socio economic problems and other factors hampering the growth of our economy?" Considering the rampant corruption and the inability of our system to tackle the same, India becoming a super power in 2050 will likely forever remain 'a dream that never came true', for our countrymen.

But all is not lost. There is still scope for change. A deep introspection into the various factors hampering our growth is needed. One such area that needs careful analysis is our Judiciary system. While the work done by the Judiciary in ensuring justice to the people who have been wronged deserves a standing ovation, it is not without its faults and weaknesses.

\footnotetext{
2 ( http://legaldesire.com/supreme-court-indias-history-originneed-know/ )
}

\section{Problems:}

$>$ Judicial Backlog: Our courts have huge backlogs. According to the official website of NBAI, there are over 30 million cases pending in Indian courts. And considering the current statistics it could take anywhere between 350 to 400 years to clear the entire backlog.

$>$ Shortage of staff: The Law commission in its $120^{\text {th }}$ report recommended the increase of the strength of the judges from the current 10.5 to 50 judges per million. The current ratio is approximately 11 judges per million. The consequence? More backlogs and more delays.

Heavy dependence on paper work. While the system of paper work has become redundant is almost every other field, the judiciary is still heavily dependent on the same. Even though efiling of documents, maintaining a legal database etc have been introduced, its only safe to say that we have a long way to go in terms of introducing the modern day technology into the judicial system which can not only help in saving time but also ensuring reduction of errors to a huge extend.

Corruption: The judiciary is supposed to be the common man's savior. It should keep a constant check on the arbitrary decisions of the authorities and settle disputes by upholding justice. But the judiciary itself has not been free from the plague of corruption. In November 2011 former Supreme Court Justice Ruma Pal, accused the higher judiciary for what she called as the seven sins. This included Plagiarism, Hypocrisy and Nepotism to name a few.

\section{Possible Solutions:}

Strengthening the Alternate Dispute Resolution System. The current system of arbitration, conciliation etc has many flaws in them. If a strong system of ADRS with limited interference from the court is developed, then the burden on the courts will definitely be decrease to a large extend.

Strong Lokpal Bill: A strong system of Ombudsman (the equivalent of Lokpal) has contributed a lot in making New Zealand one of the countries having the lowest perceived levels of corruption (as per the Corruption perception Index, 2012). Many experts believe a strong Lokpal bill can do what the system of Ombudsman has done for New Zealand. This will 
free up a lot of cases pending before the References conventional courts.

$>$ Appointment of sufficient staffs: No work can be carried out properly if there is a shortage of man power. Appoint sufficient judges. PERIOD! Passing of the Indian Judiciary Service Bill would be a good start in an effort to sort out this problem.

$>$ Simplification of procedures: Efforts should be takes to ensure the complex procedures followed are simplified to the maximum extent possible. This would not only help in saving time but also ensure speedy disposal of cases. ${ }^{3}$

\section{Websites:}

http://www.preservearticles.com/201103034384/essay -on-indian-judiciary-system.html

https://www.legallyindia.com/views/entry/a-closelook-into-the-present-day-indian-judiciary

http://legaldesire.com/supreme-court-indias-historyorigin-need-know/

\section{Books}

1. Legal and Constitutional History of India: Ancient, Judicial and Constitutional System

3 ( https://www.legallyindia.com/views/entry/a-close-look-into2. Legal History by Ramanath singh the-present-day-indian-judiciary ) 